\title{
Reproductive Choice and Decision-making: A Comparative Study amongst the Tribal and Non-Tribal Women in Assam
}

\author{
Mausumi Saha Kalita \\ Department of Economics, Kharupetia College, Assam, India \\ Corresponding author: mskalita09@gmail.com
}

Received: 27-07-2020

Revised: $18-09-2020$

Accepted: 03-10-2020

\begin{abstract}
Reproductive health of women addresses various issues of women health in many ways. It includes the issues like power to make personal decision regarding health, including sexual behaviour, choice of method of family planning, giving birth to a child etc. Thus, the study of reproductive health and behaviour of women has multi-dimensional aspects. In other words, it depends on various socio-economic and demographic factors. The present analysis has made a comparative study of the reproductive behaviour amongst the tribal and non-tribal women Undivided Darrang district of Assam (Census 2001). The study has found that Tribal women despite being the less privileged group enjoy a greater autonomy in decision-making process regarding their reproductive health.
\end{abstract}

Keywords: Child bearing, reproductive decision, contraceptives, tribal, non-tribal.

India is home to almost more than half of the world's tribal population. Tribal population constitutes 8.6 percent of India's total population (Office of the Registrar General and Census Commissioner, 2011) and is larger than that of any other country in the world. Over 84 million people belonging to 698 communities are identified as members of scheduled tribes (India Ministry of Tribal Affairs, 2004). Approximately more than 533 tribes were spread throughout different parts of India (Primary Census Abstract, 2001). On the other hand, SC population constitute 16.6 percent of total population of India (Office of the Registrar General and Census Commissioner, 2011).

Scheduled Caste and Scheduled Tribes have been formally recognised as a distinct indigenous community by the Indian constitution in 1950 and have been considered as the weakest sections of the population in view of common socio-economic and socio-demographic factors like poverty, illiteracy, lack of developmental facilities, lack of adequate primary health facilities etc (Thakur, Thakur and Saini, 1991; and Basu, 1994). Lack of awareness, lack of accessibility to health facilities, proper information and guidance are found to be the prime causes of their poor reproductive health (Kanitkar and Sinha, 1988).

How to cite this article: Kalita, M.S. (2020). Reproductive Choice and Decision-making: A Comparative Study amongst the Tribal and Non-Tribal Women in Assam. Int. J. Soc. Sci., 9(03): 205-212.

Source of Support: None; Conflict of Interest: None (1) क्ष 


\section{Differential Demographic Indicators of Women in India: Tribal and Non Tribal}

Table 1 below shows some striking demographic features of the all India women and the all India ST women based on the Report of NFHS-3, 2005-06. It is observed that 55.0 percent of the ever married women amongst the ST in India entered into the wedlock at the age of 18 years while, it is 44.5 percent amongst the ever married women at all India level. The total fertility rate of the ST women is higher (3.12) while the median age at the birth of first child for ever married ST women and the want for no more children amongst the ST women aged 25-26 years are comparatively less (19.1 years and 74.3 percent respectively).

Table 1: Selected Demographic Indicators for All Women and Scheduled Tribe Women in India

\begin{tabular}{lll}
\hline Demographic Indicators & $\begin{array}{c}\text { All India } \\
\text { Women }\end{array}$ & $\begin{array}{l}\text { All India } \\
\text { Scheduled } \\
\text { Tribe Women }\end{array}$ \\
\hline $\begin{array}{l}\text { Women of Age 20-24 Married by Age } \\
\text { 18 years }\end{array}$ & $24.5 \%$ & $55.0 \%$ \\
$\begin{array}{l}\text { Total Fertility Rate (TFR) } \\
\text { Median Age at 1 }{ }^{\text {st }} \text { Child Birth for }\end{array}$ & 19.8 & 3.12 \\
$\begin{array}{l}\text { Women 25-49 years } \\
\text { Married Women With 2 Living }\end{array}$ & $83.2 \%$ & $74.3 \%$ \\
Children Wanting No More Child & & \\
\hline Family Planning (Currently Married Women & Age 15-49 years) \\
\hline $\begin{array}{l}\text { Currently Using Any Method } \\
\text { Currently Using Any Modern }\end{array}$ & $56.3 \%$ & $48.0 \%$ \\
Method & $48.5 \%$ & $42.7 \%$ \\
Female Sterilization & $37.3 \%$ & $35.3 \%$ \\
Condom & $5.3 \%$ & $1.7 \%$ \\
Total Unmet Need & $12.8 \%$ & $13.9 \%$ \\
\hline
\end{tabular}

Source: National Family Health Survey-3, 2005-2006.

The current use of any method of family planning amongst the ever married ST women is found less (i.e. below 50 percent) while, the current use of any modern method is 42.7 percent. More than 35 percent of the ever married ST women opted for female sterilization (i.e. 35.3 percent) while, it is found 37 percent amongst the all Indian women. The use of condom is found nominal in percentage i.e. only 1.7 percent as against the total use of condom amongst the all India ever married women i.e. 5.3 percent. The total unmet need amongst the ever married ST women is found comparatively higher i.e. 13.9 percent.

The NFHS-3 shows that the demographic characteristics of the all Indian ST women differ to a great extent from that of the all India women. This causes the differential use of contraception. Hence, a comparative study of the differential socio-economic and demographic characteristics amongst the ST and non-ST women in our present study can provide us an insight view of the differential use of contraceptives amongst them.

\section{Selection of the study area}

The concentration of Scheduled Tribes varies substantially between the states and district in India (Registrar General and Census Commissioner, 2011) and is found predominantly high in a number of districts of the states such as Assam, Bihar, Madhya Pradesh, Maharashtra, Manipur, Orissa, Rajasthan, Sikkim, Tripura, Andaman \& Nicobar Islands and Daman and Diu (Census, 2001). In Assam Bodos called as Boro kachari are considered as one of the major tribe. Bodos constitute all most half of the total tribal population and 16.6 percent of the total population inthe stste.

Amongst the non-tribals of the main land area of the district i.e. the General Caste Hindu women,considered as the socio economically privileged community in the district constitute the major proportion to the total population. The other non-tribal group of respondents is the SC. The SC people are found comparatively in larger proportion in the urban area. The third group of respondents in the non-tribal category is the Muslim women who are mainly the inhabitants of rural Darrang. Recently, the female literacy rate amongst the Muslim is observed increasing though it is still below the average level.

Finally, the Char women inhabitants of the low lying flood prone area along the northern bank of the Brahmaputra River of the district, constitute 11 percent of the total population of the district (Directorate of Char Area Development Assam, 2002-03). Char people have originally migrated from the Mymensinga district of the neighbouring country Bangladesh and at present they have been living in these places for a long period. 


\section{Conceptual frame work}

The present study attempts to investigate the reproductive behaviour and the choice of contraception of the currently married women (tribal, non-tribal and Char women) in the reproductive age group (15-49 years), having at least one living child and currently using modern contraceptives in the undivided Darrang district of Assam with some selected factors. The reason for taking women of parity of one or higher is mainly because the use of contraceptive among the currently married Indian women generally commences after the birth of one child and hence it is considered to be the critical point for deciding whether to stop or space child bearing. The underlying assumption of adopting such framework is that knowledge of family planning is universal (NFHS III) and people are aware of the benefit of small family norm in the district as well.

\section{Objective of the study}

1. To make a comparative study amongst the ST (Bodo), the non ST (SC, General Caste Hindu and Muslim) women and the Char women with the differential socio-economic and demographic background.

2. To investigate factors affecting the choice of contraception amongst the currently married women of ST, non-ST and Char Muslims in the district.

\section{Methodology and materials}

The analytical part of the present study has been carried out into two parts. The first part includes the cross tabulation of the percentage distribution of currently married women with at least one living child, currently using modern contraception (terminal and spacing) by the socio-economic and demographic characteristics.

\section{Sample Coverage}

For the purpose of the study, we have selected a sample of 360 currently once married women in the reproductive age group (15-49 years) with at least one living child using modern contraceptive by stratified random sampling with proportional representation of tribal
(Bodo), non-tribal (SC,ST and General caste Hindu) population based on Census 2001. First, a purposive sample of 3 blocks is chosen. Among 3 selected blocks, 1 block is chosen from the tribal (Bodo) dominated area namely, Udalguri Development Block. Out of remaining 2 blocks one block is selected from the nontribal dominated area namely Sipajhar Development Block and the other block is selected from the Char area namely the Pub Mangaldai Development Block.

In the second stage, we have selected all total 3 villages, taking 1 from each selected block for the purpose of the study. Out of these 3 villages, first 2 villages are drawn from tribal and non-tribal dominated block containing mixed population while, the third village is chosen from the block in the char area containing only the homogeneous group of people i.e., Char Muslims ${ }^{1}$. In the urban area 3 towns- Mangaldai, Udalguri and Kharupetia have been selected purposively

In the third stage, the population of each village and towns are stratified on caste/tribe i.e. ST(Bodo), non-ST i.e. SC, General Caste i.e. Hindu and Muslim. Finally, from each stratum a sample of currently married women (15-49 years with at least one living child) using modern contraception is drawn with proportional allocation of population. Both rural and urban sample is based on the village and the ward lists of census 2001.

\section{RESULTS AND DISCUSSION}

In the present field study area it is observed that a larger proportion of the General caste Hindu women are from urban area while, women in the other categories were from rural area. Since char is a part of the rural Darrang district the proportion of the Char women are found nil in the urban sample of the present study (Fig. 1).

\section{Demographic Attributes: Tribal, Non-Tribal and Char Women}

The present study analysed the differential demographic characteristics of the tribal and non tribal (SC,General Caste Hindu, Muslim) and Char women (Table 2). The estimated current mean age is found to be lowest (i.e. 25 years) amongst the Char women while, it is found highest (i.e. 33 years) amongst the General Caste Hindu 
Table 2: Differential Demographic Attributes: Tribal, Non-Tribal and Char Women

\begin{tabular}{|c|c|c|c|c|c|c|}
\hline \multirow{2}{*}{$\begin{array}{l}\text { Demographic } \\
\text { Background }\end{array}$} & \multicolumn{2}{|c|}{ Tribal } & \multicolumn{2}{|l|}{ Non-Tribal } & \multirow{2}{*}{$\begin{array}{l}\text { Char inhabi tant } \\
\text { Char }\end{array}$} & \multirow[b]{2}{*}{ Total } \\
\hline & ST & SC & $\begin{array}{l}\text { General Caste } \\
\text { Hindu }\end{array}$ & Muslim & & \\
\hline Mean age of respondents (in years) & 31 & 30 & 33 & 30 & 25 & 31 \\
\hline Mean age at marriage (in years) & 19 & 18 & 21 & 18 & 15 & 19 \\
\hline Mean age at $1^{\text {st }}$ birth of child (in years) & 19 & 19 & 22 & 19 & 15 & 19.8 \\
\hline Mean number of living Children & 4 & 3 & 2 & 3 & 3 & 3 \\
\hline Loss of at least one Child (\%) & 39.9 & 21.2 & 13.1 & 33.6 & 60.3 & 27.2 \\
\hline \multicolumn{7}{|l|}{ Use of Family Planning } \\
\hline Total Users (\%) & 51.4 & 68.1 & 62.3 & 60.2 & 7.4 & 55.4 \\
\hline Total Non -Users (\%) & 48.6 & 31.9 & 37.7 & 39.8 & 92.6 & 44.6 \\
\hline \multicolumn{7}{|l|}{ Use of Contraception by Methods } \\
\hline Today (\%) & - & - & 1.1 & 13.2 & - & 2.7 \\
\hline Coper-T (\%) & 4.2 & - & 2.8 & - & - & 2.0 \\
\hline Con. Herbs. (\%) & 11.3 & 2.6 & - & 10.3 & - & 4.3 \\
\hline Withdrawal (\%) & - & 9.1 & 3.9 & 14.7 & - & 6.0 \\
\hline
\end{tabular}

Source: sample survey of the present study.

women. The estimated current mean age of the ST women is 31 years. The estimated mean age of the SC and Muslim women are found to be equal (i.e. 30 years).

In the Char area, where child marriage is a common practice, the mean age at marriage is found to be.15 years (i.e., below the legal age at marriage) while, it is found to be the highest amongst General Caste Hindu women (i.e. 21 years) followed by the ST (Bodo) women (19 years) and the SC and the Muslim women (18 years).

Lowest mean age lowest mean age at marriage and lower mean age at the birth of the first child of the Char women in our study have resulted in highest proportion of abortions (spontaneous) and high mean number of children. It is observed that a Char woman spends 80 percent of her reproductive life in pregnancy and lactation. On contrast, the proportion of multiple pregnancy abortion (both induced and spontaneous) has been recorded considerably high amongst the ST, SC and Muslim while, it has been found least amongst General Caste Hindu women.
The estimated mean number of living children amongst the SC and Muslim women has been recorded higher than the Char women while, it is found to be least amongst the General Caste Hindu woman (i.e. 2). On the contrary the current use of contraception is found to be highest amongst SC women (68 percent), followed by 62 percent amongst 289 General Caste Hindu women, 60 percent amongst 116 Muslim women and 51.4 percent amongst the ST Women but it is found nominal amongst the Char women i.e.7.4 percent. The use of modern spacing method is higher amongst the non-tribal group of women, while it is lower amongst the tribal i.e. the ST women in the district. Generally, lack of awareness, poverty, incentives for undergoing sterilization, have been considered as the contributory factors for accepting the female sterilization than for opting for modern spacing methods (Basu. Kapoor and Basu 2004). Onlyone method of male contraceptive (Condom) in use is found to be is highest amongst the General Caste Hindu women. The use of other reversible methods is found to be poor in the present study. 


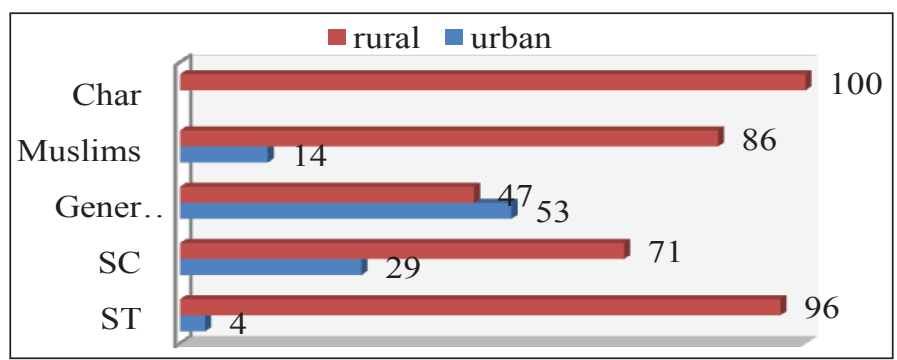

Fig. 1: R/U Distribution of Respondents : Tribal, Non-tribal Char Women $(\%)$

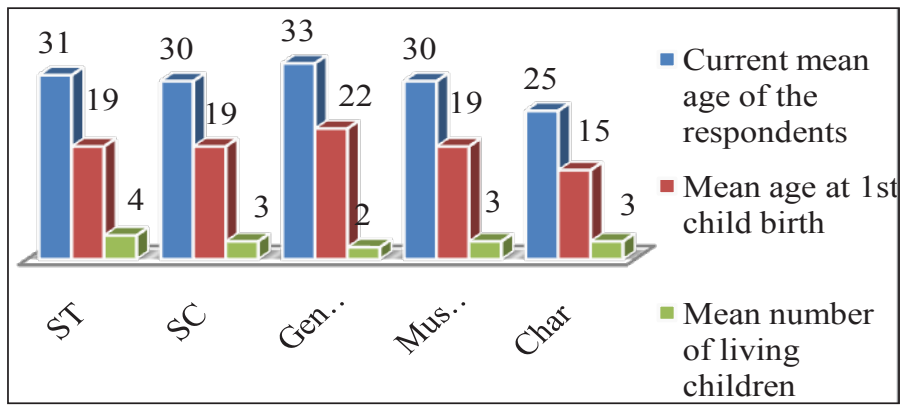

Fig. 3: Selected Demographic attribrutes: Tribal, Non-tribal \& Char Women

Source: Sample survey of the present study.

\section{Socio-Economic Attributes: Tribal, Non-Tribal and Char Women}

Like the demographic attributes the socio-economic attributes of the Char women in the present study are found to very poor compared to the women in the other counter parts. The illiteracy rate of the respondents and respondents husbands have been observed to be highest in the Char area (88.2\%) while both the rates have been found to be least amongst the General Caste Hindu women (2.4 percent) (Table 3). The majority of the respondents (82.5 percent) in our sample study are house-wife or engaged in house hold activities (including domestic farming). The proportion of service holder women is found highest amongst the General Caste Hindu (i.e. 26.0 percent) followed by the Muslim (i.e. 12.9 percent), the SC (i.e.8.8 percent) and the ST (4.3 percent).

The agrarian characteristic of the ST and the Char society has been reflected by the occupational status of the husbands. More than 55.0 percent husbands of the ST and the Char women are farmers while, the proportion

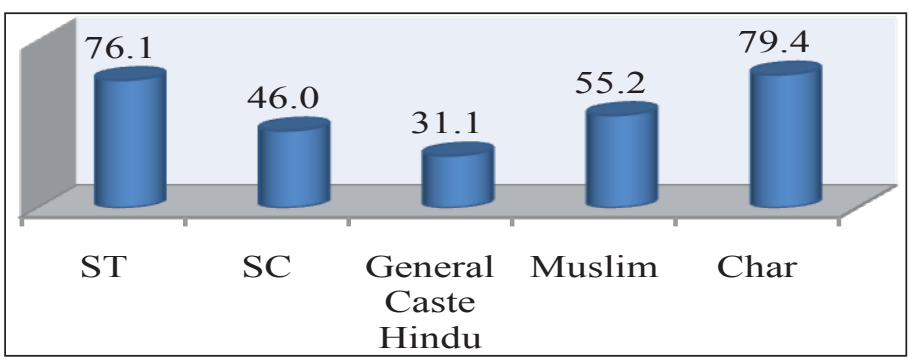

Fig. 2: Distribution of Total Abortion : Tribal \& Non-tribal women

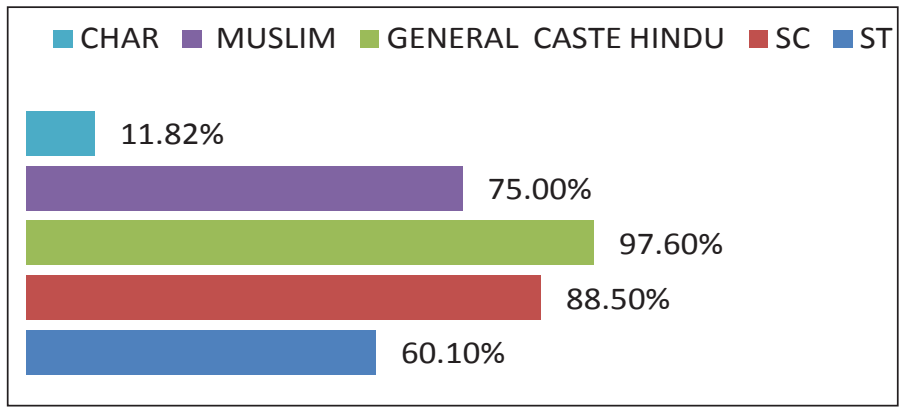

Fig. 4: \% Distribution of Literacy: Tribal, Non-tribal \& Char women Source: Sample survey of the present study.

of husbands engaged in farming. The proportion of selfemployed husbands or the traders are found highest amongst the SC. The proportion of the husbands who are service holder, are found to be highest amongst the General Caste Hindu (i.e. 56.4 percent). Majority of the families (94.01 percent) in the Char area belong to the lowest income category in our sample study i.e. less than ₹ 5000. The monthly family income and property status ST (Bodo) women and Muslim women in our sample study is found to be more or less the same while, these are found to be highest amongst the General Caste Hindu women

Husband wife discussion has been considered as one of the prime social factors that fosters the use of contraception amongst the couples. In the non-tribal category a greater proportion of SC and General Caste Hindu women are found to have discussion with their husbands. The Muslim women with comparatively a higher percentage of illiteracy hardly have any discussion with their husbands and in the char area it is found to be nil. 
Table 3: Differential Socio-Economic Attributes: Tribal, Non-Tribal and Char Women

\begin{tabular}{|c|c|c|c|c|c|c|}
\hline \multirow{2}{*}{$\begin{array}{l}\text { Socio-Economic } \\
\text { Background }\end{array}$} & \multicolumn{2}{|c|}{ Tribal } & \multicolumn{2}{|c|}{ Non-Tribal } & \multirow{2}{*}{$\begin{array}{l}\text { Char Inhabitants } \\
\text { Char }\end{array}$} & \multirow[b]{2}{*}{ Total } \\
\hline & ST & SC & $\begin{array}{l}\text { General Caste } \\
\text { Hindu }\end{array}$ & Muslim & & \\
\hline \multicolumn{7}{|l|}{ Illiteracy } \\
\hline Illiterate Husbands (\%) & 22.5 & 5.3 & 0.3 & 8.6 & 70.6 & 13.3 \\
\hline \multicolumn{7}{|l|}{ Occupation of Wives: } \\
\hline Service Holders (\%) & 4.3 & 8.8 & 26.0 & 12.9 & - & 14.6 \\
\hline \multicolumn{7}{|l|}{ Occupation of Husbands: } \\
\hline Farmer (\%) & 55.1 & 17.7 & 9.3 & 25.9 & 55.9 & 26.4 \\
\hline Traders or Self-Employed (\%) & 34.1 & 49.6 & 32.5 & 34.5 & - & 32.6 \\
\hline Daily Wage Earner (\%) & 3.6 & 2.7 & - & 3.4 & 44.1 & 5.8 \\
\hline Above ₹ $10,000 /-(\%)$ & 20.8 & 31.0 & 62.3 & 20.7 & - & 31.5 \\
\hline \multicolumn{7}{|l|}{ Property status \& other social indicators: } \\
\hline Landless (\%) & 10.2 & 12.6 & 3.6 & 7.5 & 73.5 & 10.7 \\
\hline Agricultural Land and House (\%) & 89.5 & 83.0 & 69.7 & 77.4 & 26.5 & 70.2 \\
\hline House and others $(\%)$ & - & 5.0 & 26.7 & 5.7 & - & 19.1 \\
\hline Husband Wife Discussion & 42.2 & 70.9 & 81.4 & 44.3 & - & 58.6 \\
\hline Women Exposed To Media (\%) & 97.2 & 96.3 & 98.4 & 89.5 & 2.3 & 81.6 \\
\hline Accessibility to F.P. sources (\%)(within $3 \mathrm{~km}$ ) & 90.8 & 92.0 & 94.6 & 88.1 & 23.5 & 86.5 \\
\hline
\end{tabular}

Source: sample survey of the present study.

\section{Decision Regarding Reproduction and Use of Contraception}

The decision-making power regarding the childbirth and the choice of contraception, particularly in a stereo type male dominated society lies with the husband. Many studies show that women's silent concurrence or lack of protest is interpreted as having been arrived at joint decision. It is seen generally that women neither question the decision of their husbands nor enter into any discussion with them as they do not get any support from their family members (Khan and Patel, 1996; Barneett and Stein, 2000; Padma, 2005; Padma, 2005).

Table 4 exhibits that majority proportions of the decisions are made by both husband of wife. Only exception is found in case of the ST women. Amongst the ST comparatively a larger proportion decisions are made by the women as against the women in their other counter parts. It si quite obvious that the majority proportions of the decisions amongst the Muslim respondents are found to be Husbands oriented and wife have least access to it.

The decision making power regarding the total number child bearing smaller proportion (i.e. 6.5 percent) of the decision is wife oriented while, majority are found to be joint decision. Same trend is observed in case of the SC and General Caste Hindu women. But, the ST women showed a different trend. More than one third of the ST women reported decision was wife oriented. On the contrary, more than half (i.e. 54.3 percent) of the decisions among the Muslim are husband oriented and the rest 45.7 percent are joint decision. Two in every five ST women have the decision making power regarding the total number of sons or daughters that they intend 
Reproductive Choice and Decision-making: A Comparative Study amongst the Tribal and Non-Tribal Women in Assam AessRA

Table 4: Decision Regarding Reproduction and Use of Contraception

\begin{tabular}{|c|c|c|c|c|c|c|}
\hline & Tribal & & Non-Tribal & & Char Inhabitants & \\
\hline & ST (Bodo) & SC & $\begin{array}{l}\text { General Caste } \\
\text { Hindu }\end{array}$ & Muslim & Char & Total \\
\hline \multicolumn{7}{|c|}{ Total Number of Children } \\
\hline Husband Oriented & $20.3 \%$ & $16.8 \%$ & 3.8 & $54.3 \%$ & $100.0 \%$ & $26.1 \%$ \\
\hline Wife oriented & $29.0 \%$ & $2.7 \%$ & $1.4 \%$ & - & - & $6.5 \%$ \\
\hline Joint Decision & $50.7 \%$ & $80.5 \%$ & $94.8 \%$ & $45.7 \%$ & - & $67.4 \%$ \\
\hline \multicolumn{7}{|c|}{ Total Number of Sons and Daughters } \\
\hline Husband Oriented & $10.1 \%$ & $23.9 \%$ & $11.1 \%$ & $62.9 \%$ & $100.0 \%$ & $29.6 \%$ \\
\hline Wife Oriented & $42.0 \%$ & $8.8 \%$ & $3.8 \%$ & - & - & $10.9 \%$ \\
\hline Joint Decision & $47.8 \%$ & $67.3 \%$ & $85.1 \%$ & $37.1 \%$ & - & $59.5 \%$ \\
\hline \multicolumn{7}{|c|}{ Spacing between Children } \\
\hline Husband Oriented & $2.9 \%$ & $25.7 \%$ & $10.0 \%$ & $68.1 \%$ & $100.0 \%$ & $28.7 \%$ \\
\hline Wife oriented & $59.4 \%$ & $5.3 \%$ & $7.6 \%$ & - & - & $15.2 \%$ \\
\hline Joint Decision & $37.7 \%$ & $69.0 \%$ & $82.4 \%$ & $31.9 \%$ & - & $55.9 \%$ \\
\hline \multicolumn{7}{|c|}{ Choice of Contraception } \\
\hline Husband Oriented & $31.0 \%$ & $27.3 \%$ & $32.8 \%$ & $50.0 \%$ & - & $33.9 \%$ \\
\hline Wife Oriented & $23.9 \%$ & $13.0 \%$ & $18.9 \%$ & $2.9 \%$ & $100.0 \%$ & $17.0 \%$ \\
\hline Joint Decision & $45.0 \%$ & $59.7 \%$ & $48.3 \%$ & $47.1 \%$ & - & $49.1 \%$ \\
\hline \multicolumn{7}{|c|}{ Choice of Female Sterilization } \\
\hline Husband oriented & $17.1 \%$ & $30.8 \%$ & $41.2 \%$ & $100.0 \%$ & - & $27.9 \%$ \\
\hline Wife oriented & $34.1 \%$ & $30.8 \%$ & - & - & - & $25.6 \%$ \\
\hline Joint Decision & $48.8 \%$ & $38.5 \%$ & $58.8 \%$ & - & - & $48.8 \%$ \\
\hline
\end{tabular}

Source: Sample survey of the present study.

to give birth to. Similarly a larger proportion of decision (i.e. 59.4 percent) amongst the tribal i.e. ST (Bodo) regarding the spacing between the births of two children is wife oriented.

It is worthwhile to notice that the proportion of husband oriented decision amongst the SC and the General Caste Hindu women are comparatively less in percentage than that of the Muslim. In the Char area, women do not have the decision making power. Hence, cent percent decision in the Char is found to be husband oriented.

Table 4 shows that 33.9 percent of the total use of contraceptive, in case of 401 currently married women using contraception in our sample study is husband oriented while, 17.0 percent are wife oriented and the rest i.e. 49.1 percent is joint decision. However, comparatively a higher proportion of ST women (23.9 percent) compared to non-ST women reported that the choice and the use of contraceptive is wife oriented.

\section{CONCLUSION}

The decision making power of women largely depends on the social and cultural norms of the society within which the women live in. Due to the unequal status of women in a traditional male dominated society women hesitate to take part in decision making process. But, exception is observed in the tribal (Bodo) society. Bodo women despite their lower socio-economic and demographic profile compared to the General Caste Hindu women in the field study area have been observed to have more autonomy in the choice of contraception and to decide the size or number of children (son or daughter). Women in the Muslim society are tightly bound by the traditional norms and culture and the male folk play the leading role in the decision making process. But, Muslim women with better socio-economic and demographic background compared to the Char women, is found to greater participation in the decision making process. It is also observed that amongst the 
poor, illiterate or less educated and working women, the decision regarding the choice of terminal method to limit the size of the family lies with the women as they have the financial autonomy.

Hence, finally it can be concluded that with the spread of education and urbanisation, the traditional cultural values of the society undergo a change. Female education and economic empowerment of women have been proved to be the prime pillars of capacity building in women. This ensures greater participation of women in the decision making process including the reproductive decision and hence, the freedom of choice and equal right to women.

\section{REFERENCES}

Barneett, J. and Stein, B.J. 1998. Women's Voices, Women's Lives: The Impact of Family Planning. A Synthesis of Findings From the Womens' Studies Project. North Crolina: Family Health International.

Basu, S., Kapoor K. Anoop and Basu, K.S. 2004. "Knowledge, Attitude and Practice of Family Planning Among Tribals", Journal of Family Welfare, 50N(2): 24-30.
Basu, S.K. 1994. A Health Profile of Tribal India. Health for the Millions, 2: 12-4.13.

Chatterjee, M. and Lambert, J. 1990. Women and Nutrition: Reflections from India and Pakistan. ACC/SCN Symposium Report. Nutrition Policy discussion Paper No. 6, pp. 73108, Geneva, Administrative committee on coordination / Subcommittee on nutrition.

Khan, M.E. and Patel, B.C. 1996. Male involvement in family planning: A KAP survey of Agra district Project Report, Population council.

Maiti, S., Unisa, S. and Agrawal, K.P. 2005. Health care and Health among Tribal women in Jharkhand: A Situational Analysis. Studies of Tribes and Indigenous, 3(1): 37- 46.

Padma Rama, G. 2005. Men's participation in reproductive health: a study of home villages in Andhra Pradesh. Gender and social issues in reproductive health research. Achutha Menon Centre for health science studies. Sree Chitra tribunal institute for medical science \& technology, Trivandrum, India, pp. 2-19.

Samuel L.K. and Rao P.S.S. 1992. "Socio-economic Differentials in Mothers at Risk Based on Prepregnancy Weights and Heights". Indian Journal of Medical Research, 96: 159-167. 